\title{
Treatment Outcomes of Mosaicplasty Followed by Postoperative Hyaluronic Acid Injection in Patients With Osteochondritis Dissecans (OCD) of The Knee
}

\section{Diz Osteokondritis Dissekans Lezyonlarında Mozakplasti Sonrası Hyaluronik Asit Enjeksiyonunun Tedavi Sonuçları}

\author{
Sezai Özkan, (1) Cihan Adanaş \\ Van Yuzuncu Yıl University Dursun Odabaş Medical Center Department of Orthopedics and Traumatology Van, TURKEY
}

\begin{abstract}
Aim: Mosaicplasty is a common surgical technique performed in patients with osteochondritis dissecans (OCD) of the knee. In the present study, we aimed to investigate the effectivity of mosaicplasty followed by intraarticular hyaluronic acid (HA) injection on the functional outcomes of the knee joint in patients with osteochondral lesions of the knee.
\end{abstract}

Material and Method: The retrospective study included 41 patients (32 men and 9 women) that underwent mosaicplasty due to the detection of an OCD lesion larger than $1 \mathrm{~cm} 2$ on magnetic resonance imaging (MRI). The patients were randomly divided into $\mathrm{HA}(\mathrm{n}=22)$ and control $(\mathrm{n}=19)$ groups. The HA group received $2 \mathrm{ml}$ of $\mathrm{HA}$ injection at two weeks after surgery and the control group received no additional treatment. At postoperative months 6 and 12 , functional outcomes of the patients were graded using the Lysholm knee score and pain intensity was assessed using Visual Analog Scale (VAS) in both groups.

Results: The HA group included 22 (53.7\%) and the control group included 19(46.3\%) patients. The mean age was 31.5 in the HA group and 31.47 years in the control group. The Lysholm scores at postoperative months 6 and 12 were significantly higher in the HA group compared to the control group $(p<0.01)$.

Keywors: Mosaicplasty, knee joint
Öz

Amaç: Mosaikplasti dizde osteokondritis dissekans (OCD) lezyonu olan hastaların tedavisinde yaygın olarak uygulanan cerrahi bir tekniktir Mozaikplastiden sonra eklem içi hyaluronik asit (HA) enjeksiyonunu öneren birçok çalışma olmasına rağmen, literatürde fikir birliği yoktur. Bu çalışmadaki amacımız diz osteokondral lezyonlarında uygulanan mozaikoplasti sonrası HA enjeksiyonu yapılan hastaların dizfonksiyonel sonuçlarını araştırmayı amaçladık.

Gereç ve Yöntem: Diz MR (Mağnetik Rezonans) görüntülerine göre OCD lezyonu $1 \mathrm{~cm}^{2}$ den büyük ve mozaikplasti yapılan 41 hasta (32 erkek ve 9 kadın) çalışmaya dahil edildi. Hastalar HA enjeksiyonu yapılan ve kontrol grubu olmak üzere rastgele 2 gruba ayrıldı. HA uygulanan guruba ameliyattan 2 hafta sonra diz eklemi içine $2 \mathrm{ml} \mathrm{HA}$ enjeksiyonu uygulanırken kontrol grubuna ek bir tedavi uygulanmadı. Her iki gurubun ameliyattan sonra 6. ve 12. ay daki fonksiyonel sonuçları Lysholm diz skorlama sistemi, diz ağrı seviyeleri için de Visual Analog Scale (VAS) kullanılarak karşılaştıııldı.

Bulgular:HA gurup 22 (\%53.7), kontrol gurubu ise $19(\% 46,3)$ hastadan oluşuyordu. HA gurubun yaş ortalaması 31,5 yaş ve kontrol gurubun yaş ortalaması 31,47 yaş idi. Ameliyat sonrası 6.ve 12. aydaki Lysholm skorları ve VAS değerleri HA uygulanan gurupta kontrol gurubuna göre daha yüksek olup bu fark istatistiksel olarak anlamlı idi ( $p<0.01)$.

Sonuç: Mozaikplasti sonrası diz eklemine HA uygulanması daha az ağrı olmasını ve daha iyi fonksiyonel sonuçlar elde etmemizi sağlar.

Anahtar Kelimeler: Mosaikplasti, diz eklemi, hyaluronik Asit

Corresponding (IIletişim): Sezai Özkan, Van Yuzuncu Yıl University Dursun Odabaş Medical Center Department of Orthopedics and Traumatology Van, TURKEY

E-mail (E-posta): doktorsezai@hotmail.com

Received (Geliş Tarihi): 28.12.2019 Accepted (Kabul Tarihi): 08.03.2020 


\section{INTRODUCTION}

Full-thickness articular cartilage lesions of the knee are commonly seen after sports injuries and constitute the most common type of cartilage defects in the body. ${ }^{[1]}$ These lesions rarely heal spontaneously and result in articular degeneration in advanced ages. ${ }^{[2]}$ Surgical treatment options include bone marrow stimulation (microfracture), articular cartilage replacement (mosaicplasty, osteochondral allograft transplantation), autologous chondrocyte implantation, scaffold without cells, and surface arthroplasty. ${ }^{[3,4]}$ Articular cartilage replacement (mosaicplasty) is a well-established technique used in surgical treatment of symptomatic articular cartilage defects and has been shown to provide favorable functional outcomes. ${ }^{[5,6]}$ This technique involves harvesting osteochondral grafts from non-weight-bearing areas and transplanting them to the defective site. The key advantage of the technique is the formation of hyaline cartilage rather than fibrous cartilage that forms after micro fracture and the complete filling of the defect with new hyaline cartilage, which leads to the formation of a congruent articular cartilage surface similar to that of the natural joint. ${ }^{[7,8]}$ Hyaluronic acid $(H A)$ is the mucopolysaccharide component of synovial fluid that is responsible for its viscoelastic properties. The concentration of HA decreases as osteoarthritis progresses with aging. [9,10] Intraarticular HA injection has been shown to prevent cartilage degeneration, decrease synovial inflammation, and to enhance articular proteoglycan synthesis. ${ }^{[11,12]}$ On the other hand, although mosaicplasty is commonly performed in the treatment of osteochondritis dissecans (OCD) of the knee, to our knowledge there are a limited number of studies reporting on the functional outcomes of mosaicplasty and intraarticular HA injection on the treatment of knee joint. The aim of this study was to investigate the effectivity of mosaicplasty followed by intraarticular HA injection on the functional outcomes of the knee joint and postoperative pain intensity in patients with osteochondral lesions of the knee.

\section{MATERIAL AND METHOD}

The retrospective study included 41 patients (32 men and 9 women) that presented to our clinic with a knee pain and underwent mosaicplasty due to the detection of an OCD lesion larger than $1 \mathrm{~cm}^{2}$ on magnetic resonance imaging (MRI).Patients with knee arthrosis, malalignment of the lower extremity, prior surgery for the knee joint, rheumatological diseases, and knee joint infection were excluded from the study. Mean age was 31.48 (range, 22-43) years. Surgery was performed in the right knee in 26 (63.4\%) and in the left knee in 15 (36.6\%) patients.

The lesion was localized on the medial femoral condyle in $39(95.1 \%)$ and in the left knee in 2 (4.9\%) patients. The mechanism of injury was traumatic sports injury in 23 (56.1\%), industrial accident in 7 (17.1\%), fall from height in $5(12.2 \%)$ patients and no history of trauma was present in 6 (14.6\%) patients.
Mosaicplasty was performed under general or spinal anesthesia in all patients. Following surgery, compression bandaging and cold therapy were administered in each patient. The patients were advised to avoid weight bearing in the operated extremity for 8 weeks and were instructed on how to perform active quadriceps-strengthening exercises and passive range of motion exercises.

The patients were randomly divided into HA $(n=22)$ and control $(n=19)$ groups based on postoperative HA injection. The HA group received $2 \mathrm{ml}$ of HA injection at two weeks after surgery and the control group received no additional treatment. In both groups, functional outcomes of the patients at postoperative months 6 and 12 were graded using the Lysholm knee score, which consists of 8 different items graded on a 100-point scale. ${ }^{[1]}$ Pain intensity was assessed using Visual Analog Scale (VAS) at postoperative months 6 and 12 . The patients were asked to rate their pain intensity on a 1-10 VAS scale, where 1 indicates 'no pain' and 10 indicates 'the most severe pain. ${ }^{[12]}$ In both Lysholm knee score and VAS, lower scores indicate worse outcomes while higher scores indicate better outcomes.

\section{Statistical analysis}

Data were analyzed using SPSS for Windows version 22.0 (IBM SPSS Inc., Armonk, NY, USA). Normality of gender distribution between the two groups was assessed using two-sample proportion test and the normality of age distribution was assessed using independent two-sample t-test. The Lysholm scores at postoperative months 6 and 12 were compared between the two groups using independent two sample t-test. Differences among VAS scores were determined using One-Way ANOVA test followed by post hoc Duncan's multiple comparison test. A p value of $<0.05$ was considered significant.

\section{RESULTS}

The HA and control groups comprised $81.8 \%(n=18)$ and $79 \%(n=15)$ men and $19.2 \%(n=4)$ and $21 \%(n=4)$ women, respectively. No significant difference was found between the groups with regard to gender distribution ( $p>0.05$ ).

Mean age was 31.5 in the HA group and 31.47 years in the control group. No significant difference was found between the groups with regard to mean age ( $p>0.05)$ (Table 1).

\begin{tabular}{lccc}
\hline \multicolumn{4}{l}{ Table 1. Age and gender distributions } \\
& HA group & Control group & p \\
\hline Number of patients & 22 & 19 & $>0.05$ \\
Male $(n)$ & 18 & 15 & $>0.05$ \\
Female $(n)$ & 4 & 4 & $>0.05$ \\
Mean age (years) & 31.5 & 31.47 & $>0.05$ \\
\hline HA=hyaluronic acid & & & \\
\hline
\end{tabular}

No postoperative complication was observed in both groups. However, two patients in the HA group had a short-term pain after HA injection and the pain was eliminated by a two-day cold therapy. 
The mean Lysholm score at postoperative month 6 was 78.410 in the HA group as opposed to 66.840 in the control group and a significant difference was established between the two groups $(p<0.01)$. Similarly, the mean Lysholm score at postoperative month 12 was 85.230 in the HA group as opposed to 80.840 in the control group and a significant difference was found between the two groups $(p<0.01)$ (Table 2$)$.

\begin{tabular}{llll}
\hline \multicolumn{2}{l}{ Table 2. Lysholm knee scores } & & \\
& Preoperative & $\begin{array}{c}\text { Postoperative } \\
\text { month 6 }\end{array}$ & $\begin{array}{c}\text { Postoperative } \\
\text { month 12 }\end{array}$ \\
\hline H A g r o u p $(n=22)$ & 44.545 & 78.410 & 85.230 \\
Controlgroup $(n=19)$ & 44.947 & 66.840 & 80.840 \\
P & & $<0.01$ & $<0.01$ \\
\hline HA=hyaluronic acid & & & \\
\hline
\end{tabular}

Mean VAS score at postoperative month 6 was 7.227 in the HA group and 7.000 in the control group and a significant difference was found $(p<0.01)$. Similarly, Mean VAS score at postoperative month 12 was 8.455 in the HA group and 7.737 in the control group and a significant difference was found $(p<0.01)$ (Table 3).

\begin{tabular}{lccc}
\hline Table 3. Postoperative VAS scores & & \\
& Preoperative & $\begin{array}{c}\text { Postoperative } \\
\text { month 6 }\end{array}$ & $\begin{array}{c}\text { Postoperative } \\
\text { month 12 }\end{array}$ \\
\hline H A g ro u p $(n=22)$ & 3.727 & 7.227 & 8.455 \\
Controlgroup $(n=19)$ & 3.421 & 7.000 & 7.737 \\
P & & $<0.01$ & $<0.01$ \\
\hline HA=hyaluronic acid & & & \\
\hline
\end{tabular}

\section{DISCUSSION}

The most important finding of the present study was that it objectively revealed that the administration of $\mathrm{HA}$ injection following mosaicplasty has a contributory effect on postoperative pain and functional outcomes in patients with osteochondral defects of the knee.

The primary goal in the treatment of osteochondral lesions of the knee is to prevent early articular degeneration and to restore the joint surface with a functional cartilage tissue such as hyaline cartilage. Common surgical techniques used in the treatment of osteochondral lesions of the knee include excision of the cartilaginous defect site, arthroscopic debridement, arthroscopic debridement with micro fracture, autologous chondrocyte implantation, and mosaicplasty. Previous studies reporting on the surgical treatment options for osteochondral lesions of the knee indicate that the excision of cartilage lesions alone may not provide satisfactory outcomes and that the co-administration of excision with bone marrow stimulation via the curettage of the lesion bed and micro fracture may increase the success rate to $75-90 \% .{ }^{[13-15]}$ In such lesions, autologous chondrocyte implantation is used as a well-established surgical treatment that involves expanding autologous articular cartilage cells in vitro and implanting the expanded cells into the chondral defect with a scaffold. However, the technique can be disadvantageous as it requires long durations of implementation and is administered in two phases. Moreover, the success rate of the technique is limited to $70-90 \% .{ }^{[16]}$ Mosaicplasty is a technique used in the treatment of large osteochondral defects. This technique allows complete filling of the defect with new hyaline cartilage, thereby leading to the formation of a congruent articular cartilage surface similar to that of the natural joint. Moreover, the technique has been shown to provide a success rate of $84-92 \%$. $^{[17]}$

The functional outcomes obtained in the present study were clinically more favorable compared to those reported in the literature, which could be attributed to the selection of mosaicplasty, the young age of the patients, and the administration of postoperative intraarticular HA viscosupplementation.

Intra-articular administration of exogenous HA exerts its effect by stimulating intraarticular macro homeostasis and micro homeostasis. This effect is reinforced by low-viscosity hyaluronan and high-viscosity supplementation material, which is termed macro homeostasis. ${ }^{[18]}$ Viscosupplementation restores the normal environment of collagen fibers and acts as a shock absorber and barrier, thereby providing an elasto viscous barrier under which cartilage regeneration may occur. Additionally, intraarticular HA injection has several beneficial effects on the cartilage as well, such as increasing viscoelasticity of synovial fluid, forming a protective shield on the joint surface, promoting the elasticity and firmness of the cartilage, reducing intraarticular fluid buildup, alleviating pain by stimulating pain receptors, and inhibiting the production of reactive oxygen species (ROS) and metalloproteinases by stimulating synovial cells. ${ }^{[19-21]}$

To date, intraarticular HA injection in human subjects has mostly been administered in patients with osteoarthritis and the first cases were reported by Peyron et al. ${ }^{[22]}$ Pulh et al. ${ }^{[23]}$ reported that intraarticular $\mathrm{HA}$ injection had beneficial effects in terms of pain control and cartilage regeneration. Similarly, Listrat et al. ${ }^{[24]}$ revealed that intraarticular HA injection delayed the progression of arthritis and had beneficial effects on the cartilage.

$\mathrm{HA}$ injection is thought to restore the normal viscoelastic properties of pathologically modified synovial fluid (SF) which explains the duration of this approach: "viscouple-mentation". ${ }^{[25]} \mathrm{HA}$ is thought to temporarily restore the lubricating and shock-absorbing effects of SF. Moreover, several studies have suggested that viscous supplements also reduce synovial inflammation, ${ }^{[26,27]}$ protection against cartilage erosion ${ }^{[28]}$ and support the production of intraarticular (IA) injection HA. ${ }^{[29,30]}$ Bannuru et al. ${ }^{[31]}$ reported that $\mathrm{HA}$ asserts modest positive effect for certain clinical situations up to 24 wk. HA has indirect and direct analgesic activity with joints. The indirect 
effect is through the anti-inflammatory properties of HA. The direct effect is direct inhibition of nociceptors and decreased synthesis of bradykinin and $P$ substance. ${ }^{[32,33]}$

In our study, both functional outcomes and pain scores were significantly better in the patients that received intraarticular HA injection compared to control subjects, as consistent with the literature.

Several studies indicated that the administration of arthroscopic debridement followed by intraarticular HA injection provided favorable outcomes in selected OCD patients. The studies also noted that suitable patient selection and the administration of a suitable technique followed by supplementation resulted in favorable shortand long-term outcomes. ${ }^{[34-36]}$

The present study evaluated patients with OCD of the knee and compared patients that underwent mosaicplasty alone and patients that underwent mosaicplasty followed by intraarticular HA injection. The patients that underwent both mosaicplasty and intraarticular HA injection had significantly better pain and functional scores compared to patients that underwent mosaicplasty alone. To our knowledge, the only experimental study in the literature that administered a combination of mosaicplasty and intraarticular HAinjection was conducted by Tytherleigh-Strong et al. in which the administration of mosaicplasty followed by instant intraarticular HA injection was found to have beneficial effects on graft cartilage in experimental sheep model. ${ }^{[9]}$ The findings of our study supported the findings obtained by Tytherleigh Strong et al.

\section{CONCLUSION}

In conclusion, mosaicplasty is a useful technique for the treatment of patients with $\mathrm{OCD}$ of the knee. Additionally, the administration of intraarticular HA injection following mosaicplasty may provide beneficial clinical effects. In the present study, the administration of mosaicplasty followed by instant intraarticular HA injection led to better clinical outcomes and greater patient comfort.

\section{ETHICAL DECLARATIONS}

Ethics Committee Approval: In this research, the data before 2020 was used and the research was concluded before 2020. According to the Regulation on Clinical Researches published in the Official Gazette of the Republic of Turkey with the number 28617 dated 3 November 2015, the ethics committee approval was not obtained in accordance with the article "Retrospective studies are outside the scope of the regulation (article 2- (2))". This study was prepared in accordance with the Law on Protection of Personal Data, by anonymizing patient data and in accordance with the 2013 Brazil revision of the Helsinki Declaration and guidelines for Good Clinical Practice.

Informed Consent: Because the study was designed retrospectively, no written informed consent form was obtained from patients.
Status of Peer-review: Externally peer-reviewed.

Conflict of Interest Statement: The authors have no conflicts of interest to declare.

Financial Disclosure: The authors declared that this study has received no financial support.

Author Contributions: All of the authors declare that they have all participated in the design, execution, and analysis of the paper, and that they have approved the final version.

\section{REFERENCES}

1. Gill TJ, McCulloch PC, Glasson SS, Blanchet T, Morris EA. Chondral defect repair after the microfracture procedure: a nonhuman primate model. Am J Sports Med. 2005;33:680-685

2. Marder RA, Hopkins GJ, Timmerman LA. Arthroscopic microfracture of chondral defects of the knee: a comparison of two postoperative treatments. Arthroscopy. 2005;21:152-158.

3. Prado MP, Kennedy JG, Raduan F, Nery C. Diagnosis and treatment of osteochondral lesions of the ankle: current concepts. Rev Bras Ortop.2016;51(5):489-500.

4. Murawski CD, Kennedy JG. Operative treatment of osteochondral lesions of the talus. J Bone Joint Surg Am. 2013;95(11):1045- 1054.

5. Mithoefer K, Williams RJ 3rd, Warren RF, et al. The microfracture technique for the treatment of articular cartilage lesions in the knee: a prospective cohort study. J Bone Joint Surg Am. 2005;87: 1911-1920.

6. Steadman JR, Rodkey WG, Rodrigo JJ. Microfracture: surgical technique and rehabilitation to treat chondral defects. Clin Orthop Relat Res. 2001;(391):362-369.

7. Buckwalter JA. Articular cartilage injuries. Clin Orthop Relat Res. 2002;402:21-37.

8. Frisbie DD, Trotter GW, Powers BE, et al. Arthroscopic subchondral bone plate microfracture technique augments healing of large chondral defects in the radial carpal bone and medial femoral condyle of horses. Vet Surg. 1999;28:242-255.

9. Tytherleigh-Strong G, Hurtig M, Miniaci A. Intra-articular hyaluronan following autogenous osteochondral grafting of the knee. Arthroscopy. 2005;21:999-1005.

10. Greenwald RA. Oxygen radicals, inflammation, and arthritis: pathophysiological considerations and implications for treatment. Semin Arthritis Rheum. 1991;20:219-240.

11. Tegner Y, Lysholm J. Rating systems in the evaluation of knee ligament injuries. Clin Orthop Relat Res.1985;(198):43-49.

12. Price DD, McGrath PA, Rafii A, Buckingham B. The validation of visual analogue scales as ratio scale measures for chronic and experimental pain. Pain. 1983;17(1):45-56.

13. Alparslan B, Özkan I, Acar U, Çullu E, Şavk ŞÖ. Diz ekleminde tam kat kıkırdak lezyonlarının tedavisinde mikrokırık yöntemi. Acta Orthop Traumatol Turc. 2007;41 Suppl 2:62-6.

14. Steadman JR, Miller BS, Karas SG, Schlegel TF, Briggs KK, Hawkins RJ. The microfracture technique in the treatment of full-thickness chondral lesions of the knee in National Football League players. J Knee Surg. 2003;16(2):83-6.

15. Magnussen RA, Dunn WR, Carey JL, Spindler KP. Treatment of focal articular cartilage defects in the knee: a systematic review. Clin Orthop Relat Res. 2008;466(4):952-7.

16. Brittberg M, Lindahl A, Nilsson A, Ohlsson C, Isaksson O, Peterson L. Treatment of deep cartilage defects in the knee with autologous chondrocyte transplantation. N Engl J Med.1994;331:889-895. 
17. Haklar U, Tüzüner T, Kocaoğlu B, Güven O. Mosaicplasty technique in the treatment of osteochondral lesions of the knee. Acta Orthop Traumatol Turc. 2008;42(5):344-349.

18. Robert H. Chondral repair of the knee joint using mosaicplasty. Orthop Traumatol Surg Res. 2011;97(4):418-429.

19. Asari A, Miyauchi S, Matsuzaka S, et al. Molecular weightdependent effects of hyaluronate on the arthritic synovium. Arch Histol Cytol.1998;61:125-135.

20. Kelly MA, Kurzweil PR, Moskowitz RW. Intra-articular hyaluronans in knee osteoarthritis: rationale and practical considerations. Am J Orthop.2004;33:15-22.

21. Gerald NS, Stephen LM, Kenneth DB, Elizabeth AM. Effect of intraarticular hyaluronan injection in experimental canine osteoarthritis. Arthritis and Rheumatism. 1998;41:976-984

22. Peyron JG: Preliminary clinical assessment of Nahyaluronate injection into human arthritic joints. Pathol Biol (Paris).1974;22(8):731-736.

23. Puhl W: Intra-articular sodium hyaluronate in osteoarthritis of the knee: a multicenter, double-blind study. Osteoarthritis Cartilage.1993;1 (4):233-41

24. Listrat V: Arthroscopic evaluation of potential structure modifying activity of hyaluronan (Hyalgan) in osteoarthritis of the knee. Osteoarthritis Cartilage. 1997;5(3):153-60.

25. Balazs EA, Denlinger JL. Viscosupplementation: a new concept in the treatment of osteoarthritis. J Rheumatol Suppl. 1993; 39: 3-9

26. Wang Y, Hall S, Hanna F, Wluka AE, Grant G, et all. Effects of Hylan G-F 20 supple-mentation on cartilage preservation detected by magnetic resonance imaging in osteoarthritis of the knee: a two-year single-blind clinical trial. BMC Musculoskelet Disord. 2011; 12: 195

27. Guidolin DD, Ronchetti IP, Lini E, Guerra D, Frizziero L. Morphological analysis of articular cartilage biopsies from a randomized, clinical study comparing the effects of $500-730 \mathrm{kDa}$ sodium hyaluronate (Hyalgan) and methylpredniso-lone acetate on primary osteoarthritis of the knee. Osteoar-thritis Cartilage. 2001; 9: 371-381

28. Wenz W, Breusch SJ, Graf J, Stratmann U. Ultrastructural findings after intraarticular application of hyaluronan in a canine model of arthropathy. J Orthop Res. 2000; 18: 604-612

29. Moreland LW. Intra-articular hyaluronan (hyaluronic acid) and hylans for the treatment of osteoarthritis: mechanisms of action. Arthritis Res Ther. 2003; 5: 54-67

30. Goldberg VM, Buckwalter JA. Hyaluronans in the treatment of osteoarthritis of the knee: evidence for disease-modifying activity. Osteoarthritis Cartilage. 2005; 13: 216-224

31. Bannuru RR, Natov NS, Dasi UR, Schmid CH, McAlindon TE. Therapeutic trajectory following intra-articular hyaluronic acid injection in knee osteoarthritis meta-analysis. Osteoarthritis Cartilage. 2011; 19: 611-619

32. Pozo MA, Balazs EA, Belmonte C. Reduction of sensory responses to passive movements of inflamed knee joints by hylan, a hyaluronan derivative. Exp Brain Res 1997; 116: 3-9

33. Gomis A, Miralles A, Schmidt RF, Belmonte C. Intra-articular injections of hyaluronan solutions of different elastoviscosity reduce nociceptive nerve activity in a model of osteoarthritic knee joint of the guinea pig. Osteoarthritis Cartilage 2009;17:798-804

34. Ozturk A, Ozdemir MR, Ozkan Y. Osteochondral autografting (mosaicplasty) in grade IV cartilage defects in the knee joint: 2to 7-year results. Int Orthop. 2006;30:200-204.

35. Peyron JG. Intraarticular hyaluronan injections in the treatment of osteoarthritis: State-of-the-art review. J Rheumatol.1993;20:10-15.

36. Scale D, Wobig M, Wolbert W. Viscosupplementation of osteoarthritic knees with hylan: A treatment schedule study. Ther Res. 1994;55:220-232. 